\title{
The Violence of Nonviolence: Contextualizing the Movements of King and Gandhi
}

\author{
Greg Mileski \\ Department of Religious Studies \\ University of Colorado Boulder
}

\begin{abstract}
:
King and Gandhi: two names that have come to be synonymous with nonviolence. And yet, the movements they led responded to and, in some cases with, significant violence. In a recent paper (2016), August H. Nimtz analyzes the role of violence in the movement of Dr. King, concluding that violence played a significant role in the success of the African-American Civil Rights Movement. Using Nimtz's work as a starting point, this paper analyzes King's movement and views, comparing definitions of "principled nonviolence" versus "pragmatic nonviolence." From there, this paper analyzes the role of violence in the struggle for Indian independence from British colonialism and Gandhi's own views on when, if ever, violence is appropriate. This paper concludes that, indeed, violence - that of sanctioned, statesponsored violence and that of non-sanctioned actors- has had significant roles in both of these movements. In what way, then, could these movements be said to be nonviolent? Finally, this paper asks why there remains such an impetus to identify these movements, and their leaders, with "principled nonviolence."
\end{abstract}

Keywords: Gandhi, King, Civil Rights, Nonviolence, Protest 
Amritsar. Bloody Sunday at the Edmund Pettus Bridge. Mob violence in Chauri Chaura in Uttar Pradesh. The turning of Birmingham into Bombingham. For those who witnessed the civil rights struggles of African-Americans in the American South and of Indians against British imperialism, and for those who follow in their wake as activists or students, these names have left indelible marks on our collective psyche. We often remember and celebrate these movements as examples of the power of nonviolence, the triumph of humans loving humans in the face of those who would harm the innocent. However, the history of such movements complicates the narrative of achievement through purely nonviolence. Those triumphs we today celebrate as nonviolent did not occur in vacuums, sequestered away from the violent episodes we recall. Rather, these movements are defined and contextualized by the violence that surrounded them, both the violence of the stateactors to which these movements were officially opposed and the violence of those who moved within and without these movements, with whom their ostensibly nonviolent leaders_-willingly or unwillingly, knowingly or unknowingly—succeeded in concert.

Nonviolence arises within the context of violence, as a more powerful force (state governments, here) uses its power in an oppressive or coercive way. As an oppressed population reacts, two choices present themselves: return violence in kind or oppose the oppressive power by some other means, such as nonviolent protest. In this way, nonviolent political movements can originate as a response to both oppressive and responsive violence. It is within this context that nonviolent movements ought to be understood, as they are contextualized and defined by these concurrent expressions of violence, which, as we shall see, may also play a pivotal role in the success of a nonviolent movement.

While there may be valid reasons to emphasize some aspects of an historical period over others, deemphasizing the presence of violence within these movements may serve to deny a relationship between violence and nonviolent political movements, and thus obscure the ways that nonviolent actions can serve as a response to the violence of both state actors and those operating outside the state's power structure. Understanding the ways that violence and nonviolence are related 
to one another is critical for understanding why these movements succeeded and how future movements might similarly utilize nonviolent tactics in response to the presence of violence. To acknowledge the presence of violence is not to diminish the success of these movements, but to better understand how that success occurred.

For those who theorize and attempt to systematize these political movements, an important and, one might say, moral distinction is made between principled and pragmatic (or strategic) nonviolence. In the first, sometimes equated with pacifism, ${ }^{1}$ nonviolence is an end in itself; in the second, nonviolence is a means to some other end. "Principled nonviolence is based on a rejection of all physical violence," Kevin P. Clements writes. "It rests on a willingness to suffer instead of inflicting suffering, a concern to end violence, and a celebration of the transformative power of love and compassion."2 In contrast, pragmatic nonviolence, seeing nonviolence as a means, retains the option of violence as strategic, and should the variables determining the most pragmatic path change, may utilize it. For Clements and other advocates of principled nonviolence, pragmatic nonviolence routinely falls short of principled nonviolence's loftier aim. Those who use strategic nonviolence to effect political change or achieve some measure of political power all too often-perhaps even inevitably_come to employ violent tactics themselves, annihilating what advocates of principled nonviolence see as the only worthy aim: a world free of violence. ${ }^{3}$ For Clements and other advocates of principled nonviolence, ${ }^{4}$ political movements that seek to utilize nonviolence in their struggle have a moral imperative to reject strategic nonviolence and employ principled nonviolence only.

However, if we are to analyze the success of the two movements most closely associated with principled nonviolence-the Civil Rights Movement of African-Americans in the American South and the Indian Independence Movement

\footnotetext{
${ }^{1}$ Dustin Ells Howes. "The Failure of Pacifism and the Success of Nonviolence," Perspectives on Politics Vol. No. 2 (June 2013): 428.

2 Kevin Clements. "Principled Nonviolence: An Imperative, Not an Optional Extra," Asian Journal of Peace Building Vol. 3, No. 1 (2015): 2.

3 Ibid., 6.

4 See, for instance John Howard Yoder's The Politics of Jesus (1972) and Theodore Koontz's "Christian Nonviolence: An Interpretation (2008).”
} 
opposing British imperial rule in India — the distinction between what is principled and pragmatic — and to whom this distinction applies-becomes blurry. Both movements, after all, were interwoven with violence-state- and non statesanctioned violence opposing these movements and that of activists within these movements who chose to employ violent means. Even when applied to these movements' most famous acolytes - the Rev. Dr. Martin Luther King, Jr., and Mohandas K. Gandhi-the distinction is not easily discerned, for both King and Gandhi had a complicated relationship to the violence that surrounded them. In examining these two leaders, we may be able to say that they strongly preferred to employ principled nonviolence when they believed it was possible and perhaps even strategically beneficial. However, with a wider-angle lens, it becomes apparent that violence played a key role in the success of the movements they led.

When Mohandas Gandhi returned to India from South Africa, it was with the expectation that he would apply the lessons learned therein to a national movement for Indian independence. En route, he penned his manifesto for independence, Hind Swaraj. In it, Gandhi composes a dialogue in which the most prominent voices are given space to articulate their arguments (at least, as Gandhi saw them) as to what path the independence movement should follow. Gandhi highlighted two positions at either end of the spectrum: that of the legal reformers, who were advocating for a movement within the British legal system, and that of "extremists, including anarchists and terrorists, who believe that Indian independence can be achieved only by using any means necessary, including illegal, extra-constitutional and violent means." 5 Throughout his independence movement, there would remain prominent voices advocating, even encouraging, violent uprisings. Indeed, some of his closest advisors would question the effectiveness of nonviolence, particularly when the movement seemed most doomed to fail. ${ }^{6}$

Such a pall was cast in 1919, when the potential for brutality lurking in British colonial rule was manifested in Amritsar. Gandhi had called for a national

\footnotetext{
${ }^{5}$ Douglass Allen, Mahatma Gandhi (London: Reaktion, 2011), 49-50.

${ }^{6}$ Calvin Kytle, Gandhi, Solider of Nonviolence: His Effect on India and the World Today (New York: Grosset \& Dunlap, 1969): 130.
} 
work-stoppage as a peaceful demonstration of India's unity in opposing British rule. However, almost immediately, "there were distressing incidents of violence.

Telegraph wires were cut, trains blocked, stores looted, Englishmen assaulted." ${ }^{\prime 7}$ In Amritsar, the work-stoppage had been largely peaceful; nonetheless, the British government responded with reprisals against two Congress Party members. A city which had days earlier seen a massive, peaceful demonstration, now witnessed widespread rioting in which three British men were killed. ${ }^{8}$ The soldiers dispatched to quell the violence came upon a large gathering of Indians, gathered in a U-shaped courtyard to pray amid the violence. Under the command of Brigadier-General Reginald Dyer, they opened fire, killing nearly 400 and injuring over 1500 more. ${ }^{9}$ The victims were then left through the night "without water or medical attention.",

The brutality of the Amritsar Massacre shocked the nation and catalyzed political action. "Within a month, the [ruling British] government had turned conciliatory. The Indian National Congress was permitted to hold its 1919 annual meeting near Amritsar. Most of the political prisoners... were released in time to attend."11 In addition to the sympathetic response from the British, the violence also brought widespread publicity and a palpable sense of urgency to the independence movement. ${ }^{12}$ Gandhi, and India with him, now saw full independence as the only option and the Gandhian swaraj movement gained momentum nationwide. ${ }^{13}$ What would have followed an entirely peaceful national work stoppage is difficult to say, but it does seem that the violence that escalated to such a horrifying degree focused attention on Gandhi's message of nonviolence, amplifying it and creating a stark contrast with the violence just witnessed.

In 1922, in the midst of the national satyagraba campaign, violence again broke out amid Indian protesters. Riots in Uttar Pradesh, for instance, resulted in

\footnotetext{
${ }^{7}$ Ibid., 118.

8 Ibid., 118,

${ }^{9}$ Allen, Mahatma Gandhi, 58.

${ }^{10}$ Kytle, Gandhi, 119.

11 Ibid., 121.

12 Allen, Mahatma Gandhi, 58.

13 Ibid.
} 
the deaths of twenty-one British police officers. ${ }^{14}$ Gandhi, much to the consternation of a young Jawaharlal Nehru, called for an end to the campaign. The British authorities responded by arresting Gandhi and sentencing him to six year's imprisonment, though between his sentencing and his incarceration, a staggering fifty thousand Indian political prisoners were released. ${ }^{15}$ Whether or not the violence that had occurred two years earlier in and around the Amritsar Massacre was on the mind of British authorities at the time is unknown, but it would not be surprising if imprisoning Gandhi conjured fears of an escalation of violence meant to be quelled by the large gesture.

Gandhi's own views on the appropriateness of violence are, like much about Gandhi, subject to the interpreter's lens. While he is well known for advocating nonviolence, his views are not systematized and thus can seem inconsistent, even contradictory. Douglass Allen writes that "Gandhi himself sometimes conveys the impression that he is a simple, rigid, uncompromising absolutist with respect to violence, nonviolence, war, peace, vows, principles and rules, and other ethical and spiritual concepts and values," but that a closer look at Gandhi's writings reveals that he sees a need for nuance and contextualization ill at-ease with advocates of an absolute nonviolence. ${ }^{16}$

Early in his activism, for instance, Gandhi participated in two British-led South African military campaigns, albeit wielding a stretcher to aid the wounded rather than a rifle to make more of them. When the First World War broke out, "he actively recruit[ed] in India for the British war effort," ${ }^{17}$ and he later offered qualified support for Indian participation in World War II. ${ }^{18}$

Despite the dismay of some of his colleagues, Ignatius Jesudasan sees this as consistent with his views during this early period, writing that Gandhi "saw no inherent contradiction between satyagraba and warfare."19 Later in Gandhi's writings,

\footnotetext{
14 Ibid., 59

${ }^{15}$ Kytle, Gandhi, 130.

16 Allen, Mahatma Gandhi, 124-125.

17 Ibid., 47-48.

18 Ibid., 90.

${ }^{19}$ Ignatius Jesudasan, S.J., A Gandhian Theology of Liberation (Maryknoll: Orbis, 1984), 54.
} 
he demarcates more explicitly those times when violence is acceptable, naming euthanasia and the defense of one's community among them. ${ }^{20}$ In analyzing Gandhi's view on violence, Ronald Terchek writes: "What we have with these exceptions is Gandhi's nonperfectionism regarding nonviolence and find him problematizing his own commitments to nonviolence." ${ }^{21}$ That is, Gandhi's relationship to violence and his advocacy of nonviolence do not fit well into essentialized boxes. While it is clear that Gandhi zealously advocated nonviolence, a creed he seems to have lived by stridently in his own life, it also seems that Gandhi believed that there were contexts and situations in which a violent response could bring about a more desirable outcome than a nonviolent one could.

A little over a decade after Gandhi's death, Dr. Martin Luther King, Jr., with his wife Coretta Scott King and Dr. Lawrence D. Reddick, a history professor at Alabama State University, traveled to India to learn from Gandhi's colleagues in the struggle for Indian independence. King wrote of Gandhi that he "was the guiding light of our technique of nonviolent social change," 22 and that "he is one of the halfdozen greatest men in world history." 23 It is not surprising, then, that the movements led by these men shared so many similarities.

Though a tireless advocate for nonviolent strategies, King displayed a nuanced understanding of the relationship to the violence occurring in his movement, both critiquing and empathizing with the perpetuators, and perhaps even employing the threat of violence to catalyze political action. To begin, King did not fashion himself a proponent of principled nonviolence. In "The Social Organization of Nonviolence," King considered three possible reactions to state-sponsored violence he might encourage his followers to employ. The first is what is called

\footnotetext{
${ }^{20}$ Ronald J. Terchek, "Gandhi: Nonviolence and Violence," Journal of Power and Ethics: An Interdisciplinary Review Vol. 2, No. 3 (2001): 234.

${ }^{21}$ Ibid., 235.

22 Martin Luther King, Jr., "My Trip to the Land of Gandhi," in A Testament of Hope: The Essential Writings of Martin Luther King, Jr., ed. James Melvin Washington (San Francisco: Harper \& Row, 1986), 23.

23 Ibid., 26.
} 
above "principled nonviolence" and what King called "pure nonviolence," 24 an absolute prohibition against any engagement with retributive violence. The second was "violence in self-defense, which all societies... accept as moral and legal." 25 The third is the open encouragement of organized violence-an option King rejected out of hand. But King also rejects the first option, that of principled or pure nonviolence, as too impractical for a mass movement, noting that it "cannot readily or easily attract large masses, for it requires extraordinary discipline and courage."26 The second option, then, that of violence in service of self-defense was a position with which King was comfortable. Indeed, as August H. Nimtz observes, King "was not wedded as is usually assumed to nonviolence in principle or as a strategy to be practiced at all places and times, but rather nonviolence as a tactic, given the circumstances in which the movement operated." ${ }^{27}$ Indeed, the violence of the supporters of the status quo, as well as the threat and-at times, presence-of violence within the movement itself may have contributed in some ways to its success.

The American Civil Rights Movement was, first and foremost, a response to the systemized violence deployed against African Americans in the American South, a violence King regularly articulated, as in Where Do We Go from Here?:

American Negroes have not been mass murderers. They have not murdered children in Sunday school, nor have they hung white men on trees bearing strange fruit. They have not been hooded perpetrators of violence lynching human beings at will and drowning them at whim. ${ }^{28}$

The violence of American chattel slavery gave way to the legalized dehumanization of Jim Crow, and as African Americans responded in opposition to this violence, the

${ }^{24}$ Martin Luther King, Jr, "The Social Organization of Nonviolence," in A Testament of Hope: The Essential Writings of Martin Luther King, Jr., ed. James Melvin Washington (San Francisco: Harper \& Row, 1986), 33.

${ }^{25}$ Ibid.

26 Ibid.

${ }^{27}$ August H. Nimtz, "Violence and/or Nonviolence in the Success of the Civil Rights Movement: The Malcom X-Martin Luther King, Jr. Nexus," New Political Science Vol. 38, No. 1 (2016): 5.

${ }^{28}$ Martin Luther King, Jr., "Where Do We Go from Here?" in A Testament of Hope: The Essential Writings of Martin Luther King, Jr., ed. James Melvin Washington (San Francisco: Harper \& Row, 1986), 595. 
state and those who supported the state-sponsored status quo continued this violence against black bodies. The dogs, firehoses, and night sticks of Bull Conner and others were supplemented by Klan bombings like that of Sixteenth Street Baptist Church (which King referenced above), killing four African American children attending Sunday school. ${ }^{29}$

These and other instances of violence lead Nimtz to conclude that violence played a defining role in the Civil Rights Movement and that it was both violent and nonviolent responses to the violence of state- and non state-actors that resulted in the most public of the Civil Rights Movement's successes. Indeed, at times, the Civil Rights Movement intentionally provoked violence from the state and its supporters, in order to raise the tension and the stakes of the movement, as well as to reveal the violent and dehumanizing nature of state-sponsored discrimination. ${ }^{30}$ James Calaiaco notes that King's "critics were correct in noting that his nonviolent method was most successful when it provoked violence from the defenders of the racist order." 31 Particularly during the Birmingham campaign, the activists within the Civil Rights Movement deliberately and successfully sought to provoke state-sponsored retaliatory violence against peaceful protestors. ${ }^{32}$ Calaiaco writes that this apparent and visible violence "stirred the nation's conscience by making evident the injustice that had always existed, but under the cloak of legitimacy." ${ }^{33}$ King himself was forthright about this tactic, writing in his Letter from Birmingham City Jail: "Nonviolent direct action seeks to create such a crisis and establish such creative tension that a community that has constantly refused to negotiate is forced to confront the issue. It seeks to so dramatize the issue that it can no longer be ignored." 34 The images of the resulting violence shocked observers around the country, providing visceral and memorable images of the ongoing, general violence of the state and its supporters.

\footnotetext{
${ }^{29}$ Nimtz, "Violence and/or Nonviolence," 13.

${ }^{30}$ Nimtz, "Violence and/or Nonviolence," 2.

${ }^{31}$ James A. Calaiaco, "Martin Luther King, Jr and the Paradox of Nonviolent Direction Action," in Martin Luther King, Jr and the Civil Rights Movement: Controversies and Debates, ed. John A. Kirk (New York: Palgrave MacMaillan, 2007), 97.

32 Nimtz, "Violence and/or Nonviolence," 8.

33 Calaiaco, "Paradox of Nonviolent Direct Action," 98.

${ }^{34}$ Martin Luther King, Jr., "Letter from Birmingham City Jail," in A Testament of Hope: The Essential Writings of Martin Luther King, Jr., ed. James Melvin Washington (San Francisco: Harper \& Row, 1986), 291.
} 
It was, then, the violence of supporters of the status quo that elevated awareness of the struggle for civil rights as a matter of life and death.

There were those within the Civil Rights Movement who argued that the violence of the state and its allies ought to be met in kind, most famously by the leadership of the Nation of Islam and by Malcolm X. Speaking in 1964, Malcom, who had recently left the Nation to be more engaged with the Civil Rights Movement, said that the time had come to consider violence a legitimate tool in achieving the movement's ends: "In 1964, it's the ballot or the bullet." 35 Following the bombings in Birmingham, many of King's compatriots came to openly question the appropriateness of a nonviolent response to such an atrocity, ${ }^{36}$ as riots erupted in Birmingham. ${ }^{37}$

While King chastised those threads within the Civil Rights Movement advocating violence, he also recognized common cause with them. During the Birmingham campaign, he joined Jeremiah X, then leader of the Nation, on stage at a rally, and spoke of nonviolence with his arm draped around his shoulder-a sort of apophatic reminder of the potential for violence that lurked within the Civil Rights Movement and, perhaps, an implicit threat to the state. ${ }^{38}$ Only a week later, King would write his Letter from Birmingham City Jail, aware that the state faced three options going forward: deal with neither the Nation nor with King and maintain the status quo, deal with the Nation and risk an escalation of the violence, or deal with King. ${ }^{39}$ It was the very real presence of those advocating violence that amplified King's nonviolent approach, while also lifting up his more violent counterparts as plausible but less desirable alternatives. ${ }^{40}$

\footnotetext{
35 Malcolm X, quoted at length in Nimtz, "Violence and/or Nonviolence," 14.

36 Ibid., 13.

${ }^{37}$ Ibid., 8.

38 Ibid., 7.

${ }^{39}$ King, "Letter from Birmingham City Jail," 297.

${ }^{40}$ Nimtz, "Violence and/or Nonviolence," 14.
} 
This presence of violence, implicitly or explicitly, on the side of the supporters of the status quo and within the movement itself, and the threat of its escalation, was not lost on the federal government. Again, Nimtz:

If respect and empathy were the reaction of most people to the CRM [Civil Rights Movement], that of US rulers can be summed up in one word: fear. Despite southern Blacks' initial scrupulous and heroic adherence to nonviolence, their mass movement for equality—along with the often less polite risings of millions across the colonial world - rang on US rulers' ears with the same hair-raising, everfeared words: the natives are restless. ${ }^{41}$

Nimtz goes on to analyze the ways that violence and the threat of violence seem to have catalyzed the political response that made both the Civil Rights Act and the Voting Rights Act possible. Following the Birmingham riots, Nimtz quotes both Attorney General Robert and President John Kennedy remarking worriedly about further violence in the city and being so motivated to deploy National Guard troops, if necessary, to enforce local settlement that recognized the demands of the protestors. ${ }^{42}$ That is, it was the possibility of escalating violence that motivated the federal government to ensure that the victory won in Birmingham was maintained.

Likewise, following Malcom X's above-referenced "Ballot or the Bullet" speech, Nimtz illustrates the change President Lyndon Johnson underwent. Johnson assumed office planning to deprioritize the Voting Rights Act. ${ }^{43}$ However, activism on the ground continued, culminating in the now-infamous attempted crossing of the Edmund Pettus Bridge. Two days after what would come to be known as "Bloody Sunday," Johnson introduced the Voting Rights Act to Congress. Over the course of his televised speech, Johnson mentioned three turning points in American history: Lexington and Concord, Appomattox, and Bloody Sunday. ${ }^{44}$ It was, Nimtz argues, the brutal violence by the state that forced Johnson's hand, requiring him to answer the threat that violence would escalate if the nonviolent tactics of the marchers at the Edmund Pettus Bridge were not rewarded with success. In this way,

\footnotetext{
${ }^{41}$ Ibid., 2.

42 Ibid., 9.

${ }^{43}$ Ibid., 17.

${ }^{44}$ Ibid., 19.
} 
then, it was the violence of the state and its allies that dramatized the conflict in the American South, and the threat of violent reprisals by protestors that would result in escalating violent encounters, that propelled the federal government to recognize the validity and the importance — and to ultimately ensure the success — of the nonviolent elements of the Civil Rights Movement.

It is too much to claim that the American Civil Rights movement or the Indian Independence struggle succeeded because of violence, or would not have succeeded without violence. Likewise, it stretches the boundaries of the historical record to suggest that King and Gandhi willfully and tactically employed violence when it suited their ends. However, it is clear that the success of these historical movements - with the passage of two major pieces of legislation in the American case and British withdrawal in the Indian-cannot be divorced from the violence that surrounded, affected, and motivated them. Despite King and Gandhi's admonitions, violence was a major component of their struggles. While these figures were staunch and powerful advocates for nonviolence, the movements of which they were a part contained violently reactive elements responding to the violence of state oppression. It was the violence of state actors and their allies that elevated these struggles to matters of life and death, and it was - both the potential and actualviolent response of some among the oppressed that elevated and amplified the nonviolent tactics of both Gandhi and King. In these ways, the movements led by these visionaries were not isolated from the presence of violence but rather were contextualized and propelled by it.

While it may be tempting to conclude that nonviolent movements require and so should welcome a violent counterpart, this obscures the primary role of nonviolence: response to the violence of others, both within and without liberation struggles. That is, the oppression of peoples is itself a violent activity and so can engender a violent response. It is into this dynamic that nonviolence enters, as a response to this violence. Rather than concluding that nonviolent movements should welcome a violent counterpart, it is the presence of violence within a liberation struggle that may create the opportunity for a successful nonviolent movement. Thus, it is not the case nonviolent movements should court or welcome 
violence, but that political violence cries out for a nonviolent counterpart to act as an effective intermediary between violent factions and to provide a means for the deescalation of the threat of violence. 


\section{Bibliography}

Allen, Douglas. Mahatma Gandhi. London: Reaktion, 2011.

Calaiaco, James A. "Martin Luther King, Jr and the Paradox of Nonviolent Direct Action," in Martin Luther King, Jr and the Civil Rights Movement: Controversies and Debates, ed. John A. Kirk, 95-110. New York: Palgrave Macmillan, 2007.

Clements, Kevin P. "Principled Nonviolence: An Imperative, Not an Optional Extra." Asian Journal of Peacebuilding Vol. 3, No 1 (2015): 1-17.

Howes, Dustin Ells. "The Failure of Pacifism and the Success of Nonviolence." Perspectives on Politics Vol. 11, No. 2 (June 2013): 427-446.

Jesudasan, S.J., Ignatius. A Gandhian Theology of Liberation. Maryknoll: Orbis, 1984.

King, Jr., Martin Luther. "Letter from Birmingham City Jail," in A Testament of Hope: The Essential Writings of Martin Luther King, Jr., ed. James Melvin Washington, 289-302. San Francisco: Harper and Row, 1986.

. "The Social Organization of Nonviolence." A Testament of Hope: The Essential Writings of Martin Luther King, Jr., ed. James Melvin Washington, 31-34. SanFrancisco: Harper and Row, 1986.

. "Where Do We Go from Here: Chaos or Community?” A Testament of Hope: The Essential Writings of Martin Luther King, Jr., ed. James Melvin Washington, 555-633. San Francisco: Harper and Row, 1986.

Kytle, Calvin. Gandhi: Soldier of Nonviolence: His Effect on India and the World Today. New York: Grosset and Dunlap, 1969.

Nimtz, August H. "Violence and/or Nonviolence in the Success of the Civil Rights Movement: The Malcolm X-Martin Luther King, Jr. Nexus." New Political Science Vol. 38, No. 1 (2016): 1-22.

Terchek, Ronald J. "Gandhi: Nonviolence and Violence." Journal of Power and Ethics: An Interdisciplinary Review Vol. 2, No. 3 (2001): 213-242. 